\title{
Selected aspects of biopsychosocial functioning of the senior national team in cycle speedway representing Poland in 2015 at the World Championships in Poole
}

\author{
Bakota D. ${ }^{\mathrm{ABDE}}$, Ortenburger D. ${ }^{\mathrm{ABC}}$, Płomiński A. ${ }^{\mathrm{BDE}}$ \\ Jan Dlugosz University of Częstochowa, Institute of Physical Education, Tourism and Physiotherapy, Poland
}

Authors' Contribution: A - Study design; B - Data collection; C - Statistical analysis; D - Manuscript Preparation; E - Funds Collection.

\begin{abstract}
Purpose: $\quad$ to increase knowledge concerning certain elements of biological and psychological functioning of contestants practising speedway cycling through examining typical health behaviours, the mental approach, and preventive behaviours applied to everyday functioning.

Material: $\quad$ the study sample consisted of 12 cycle speedway competitors (aged between 20 and 37, average 27.42 \pm 5.68 ). The research concerned a group of speedway riders, Polish national senior representatives in speedway cycling at the World Championship. The Standardized Inventory of Health Behaviours and our own questionnaire were applied.

Results: $\quad$ the mean value of the general health behaviour index was $75.50 \pm 14.0(\mathrm{~N}=12)$. The value of the coefficient between positive mental approach and satisfaction experienced by the competitors caused by progress within a year was $r=0.62 ; p<0.05$. In the group the value of the index of satisfaction caused by obtained progress in improving condition was: median 6.50. Based on the performed analysis, it was found that as for the health behaviour types in the group of cycle speedway competitors there were two smaller groups $(p<0.05)$.

Conclusions: based on the presented research results, we can say that a group of senior competitors representing Poland at the championship in 2015 in cycle speedway is internally divided with respect to the revealed health behaviour type. The findings of the study suggest that there are still potential opportunities to be used by competitors surveyed, which in the future may lead to continued excellent - as at present - and even better performance at competitive events.

Keywords: $\quad$ sports psychology, development, cycle speedway, Poland, psychological, measurement.
\end{abstract}

\section{Introduction}

Obtaining maximum effectiveness in championship competitions in cycle speedway is associated with enormous effort, complex skills, predisposition and other factors, which are the subject of growing scientific knowledge [1, 2].

Successes of the Polish senior national team in cycle speedway are a manifestation of such effectiveness. This has become the inspiration for preparing this paper, which starts by outlining the history of cycle speedway in Poland and achievements of Poles in this discipline at the world championships in the years 1995-2015.

Cycle speedway (bicycle racing on shale tracks) came to Poland from England at the beginning of the 1990s. The first section of this discipline was established at "Union" Leszno. In turn, the first club in Poland which was entered in the register of physical culture associations as a cycle speedway club was Rawicz Sports Club "Pavart", established in 1994 [3]. A year later, also in Rawicz, the Provisional Polish Society of Cycle Speedway was established (since 1997 the Polish Society of Cycle Speedway). Next, on 30 November 2005, the Polish Federation of Cycle Speedway Clubs was registered in court, which replaced the pre-existing Polish Society of Cycle Speedway.

In cycle speedway sport there are two Polish national

(c) Bakota D., Ortenburger D., Płomiński A, 2018

doi:10.15561/18189172.2018.0202 teams:

- the senior national team with a coach and head of the team and the professional team appointed by name;

- the junior (competitors up to 18 years of age) national team with a coach and head of the team and the professional team appointed by name. In addition, in 2011, for a series of test matches with the United Kingdom, the women's team was appointed.

Poles have been participating in the World Individual and Team Championships since 1995. Since 2003 the World Championships of Pairs have also been held, in which Polish cycle speedway riders have won medals from the very beginning (Table 1).

This paper concerns certain aspects of biopsychosocial functioning of competitors engaged in cycle speedway. Competitors who take part in the championships at the world level, such as the Polish senior national team in cycle speedway, face very high requirements in terms of technical, tactical and physical preparation as well as handling the challenge psychologically.

Some of the challenge that championship competitions consist of is the speed at which the distance is covered, the necessity of full concentration and of no distraction during the competition, and many other factors of biological and psychological nature. In accordance with the biopsychic perspective the process of preparation and performance must be perceived as a whole, while paying attention to the fact that these are processes that are stretched in 
Table 1. Successes of Poles at Individual World Championships (IWC), Team World Championships (TWC) and World Championships of Pairs (WCP) in the years 1995-2015

\begin{tabular}{|c|c|c|c|c|c|c|}
\hline Year & Venue & $\begin{array}{l}\text { IWC } \\
\text { Place on } \\
\text { the podium }\end{array}$ & Competitors & $\begin{array}{l}\text { TWC } \\
\text { Place of Poland } \\
\text { on the podium }\end{array}$ & $\begin{array}{l}\text { WCP } \\
\text { Place on } \\
\text { the podium }\end{array}$ & Competitors \\
\hline 1995 & $\begin{array}{l}\text { United } \\
\text { Kingdom }\end{array}$ & - & - & 3 & - & - \\
\hline 1997 & Australia & - & - & - & - & - \\
\hline 1999 & Poland & $\begin{array}{l}2 \\
3\end{array}$ & $\begin{array}{l}\text { Damian Woźny } \\
\text { Karol Włodarczyk }\end{array}$ & 1 & - & - \\
\hline 2001 & Australia & - & - & 3 & - & - \\
\hline 2003 & $\begin{array}{l}\text { United } \\
\text { Kingdom }\end{array}$ & 3 & Łukasz Nowacki & 2 & 1 & $\begin{array}{l}\text { Marcin Szymański } \\
\text { Dominik Rycharski } \\
\text { Damian Woźny }\end{array}$ \\
\hline 2005 & Australia & - & - & 2 & 1 & $\begin{array}{l}\text { Łukasz Nowacki } \\
\text { K. Szymański } \\
\text { P. Kozłowski }\end{array}$ \\
\hline 2007 & Poland & $\begin{array}{l}1 \\
2 \\
3\end{array}$ & $\begin{array}{l}\text { Marcin Szymański } \\
\text { Maciej Ganczarek } \\
\text { Radosław Handke }\end{array}$ & 1 & 1 & $\begin{array}{l}\text { Marcin Szymański, } \\
\text { Maciej Ganczarek, } \\
\text { Rafał Duliński }\end{array}$ \\
\hline 2009 & Australia & 3 & Łukasz Nowacki & 2 & 1 & $\begin{array}{l}\text { Marcin Szymański, } \\
\text { Maciej Ganczarek, } \\
\text { Łukasz Nowacki }\end{array}$ \\
\hline 2011 & USA & 1 & $\begin{array}{l}\text { Łukasz Nowacki } \\
\text { Rafał Duliński }\end{array}$ & 3 & 2 & $\begin{array}{l}\text { Łukasz Nowacki } \\
\text { Przemysław } \\
\text { Binkowski } \\
\text { Marcin Paradziński }\end{array}$ \\
\hline 2013 & Australia & 1 & Marcin Szymański & 1 & 1 & $\begin{array}{l}\text { Marcin Szymański } \\
\text { Przemysław } \\
\text { Binkowski } \\
\text { Łukasz Nowacki }\end{array}$ \\
\hline 2015 & $\begin{array}{l}\text { United } \\
\text { Kingdom }\end{array}$ & 1 & $\begin{array}{l}\text { Bartosz } \\
\text { Grabowski }\end{array}$ & 1 & 1 & $\begin{array}{l}\text { Marcin Szymański } \\
\text { Bartosz Grabowski }\end{array}$ \\
\hline
\end{tabular}

time, constituting a significant part of everyday life, at the biological, psychological and social level. The biopsychosocial model is a general model or approach stating that biological, psychological and social factors all play a significant role in human functioning in the context of sport and everyday life [4-6].

The essential elements are awareness of the role of nutrition and proper diet, weight control, special attention to one's health, the pursuit of rigorous training objectives, getting enough sleep, maintaining a positive mental attitude despite the hardship of training, and perseverance in an aspiration to improve skills. Under the literature of health psychology, health habits do not constitute a uniform construct of notions.

The aim of this study is to increase knowledge concerning certain elements of biological and psychological functioning of contestants practising speedway cycling through examining typical health behaviours, the mental approach, and preventive behaviours applied to everyday functioning.

The focus of the deliberations has been the area of functioning, approached from the biopsychic perspective with the following research questions asked:

- How are individual manifestations of health behaviour shaped in day-to-day functioning?

- Is there a relationship between mental attitude and the satisfaction with training progress?

- Do top competitors, representing the highest level in cycle speedway, constitute a homogeneous group in terms of health behaviour showed and a sense of personal competence?

- How is a sense of personal competence of the senior 
team in cycle speedway shaped?

\section{Material and Method}

Participants. The research concerned a group of 12 cycle speedway riders, male, Polish national senior representatives in speedway cycling in 2015 at the World Championship, aged between 20 and 37 (average $27.42 \pm 5.68)$. The conducted research has a self-descriptive character. The presented questionnaires are completely voluntary and anonymous.

Research tools:

Questionnaires of an accepted psychometric value, used in health psychology, were applied in the research: the Inventory of Health Behaviours and the Sense of Personal Competence Scale.

The Inventory of Health Behaviours contains statements describing different types of behaviour connected with health. Considering the frequency of behaviours indicated in the research, the general intensity of health behaviours is established, i.e. proper eating habits, preventive behaviours, health practices and positive mental attitude. This inventory may help in creating preventive programmes establishing the directions of behaviour modification that influences the general functioning and monitoring changes in health practices.

Questionnaires of an accepted psychometric value, used in health psychology, were applied in the research [7, 8]. Additionally, in the presented research the data were gathered using a self-designed questionnaire including open and closed questions. Open questions concerned the motives of undertaking this sport discipline, subjective assessment of progress with condition, and satisfaction of successes in a particular year.

Statistical analysis

Statistical analysis was used. Due to the fact that the obtained data are of a self-descriptive character (they derive from surveys and questionnaires), the analysis was performed using methods that are recommended for processing "non-acute", imprecise data that frequently occur in the humanities and health sciences. The data were subjected to statistical analysis for the purpose of interpretation. Descriptive statistics such as mean, standard deviation, lower and upper quartiles and others were computed to analyse the interdependence between the variables $[9,10]$. In order to assess the empirical data in a taxonomical way, the classification algorithm, belonging to the group of algorithms known under the common name cluster analysis, was applied.

\section{Results}

The obtained results are presented in tables 2-5. Table 2 contains descriptive statistics concerning the types of behaviour associated with health that often appear in the case of a particular person. Table 3 presents the values of a positive mental approach index and the value of the index of satisfaction caused by progress obtained in the last year. Table 4 presents the results that are the effect of cluster analysis, aimed at evaluating the homogeneity of the group of competitors with respect to the revealed types of health behaviour and the feeling of personal competence $(\mathrm{N}=12)(\mathrm{p}<0.05)$. Table 5 presents the results indicating the feeling of personal competence among cycle speedway competitors.

The correlation between positive mental attitude and satisfaction with the degree of the growth of one's fitness as a result of systematic training was: $r=0.62 ; \mathrm{p}<0.05$; $\mathrm{N}=12$ (Figure 2).

Based on the calculations, it was found that the indicator of median satisfaction with the progress made during a given year was 6.50 (Table 2 ).

On the basis of the study, it was found that in the group surveyed there are relatively high values of positive mental attitude indicators. A correlation was found between a positive mental attitude and satisfaction with the progress made in training within a year.

Table 2. The health-related behaviour, usually in everyday functioning, descriptive analysis.

\begin{tabular}{lllllllll}
\hline $\mathbf{N = 1 2}$ & Median & Min & $\max$ & $\begin{array}{l}\text { Lower } \\
\text { quartile }\end{array}$ & $\begin{array}{l}\text { Upper } \\
\text { quartile }\end{array}$ & Range & $\begin{array}{l}\text { Interquartile } \\
\text { range }\end{array}$ & Skewness \\
\hline Age & 26.50 & 20.00 & 37.00 & 22.50 & 31.50 & 17.00 & 9.00 & 0.30 \\
Proper feeding habits & 18.50 & 8.00 & 27.00 & 16.00 & 25.00 & 19.00 & 9.00 & -0.26 \\
Preventive behaviours & 21.50 & 14.00 & 26.00 & 18.00 & 22.00 & 12.00 & 4.00 & -0.38 \\
Positive mental attitude & 18.00 & 13.00 & 23.00 & 15.00 & 20.50 & 10.00 & 5.50 & 0.03 \\
Health habits & 17.00 & 11.00 & 25.00 & 14.50 & 23.00 & 14.00 & 8.50 & 0.17 \\
\hline
\end{tabular}

Table 3. Positive attitude and satisfaction with the degree of the growth of one's fitness as a result of systematic trainings, descriptive analysis.

\begin{tabular}{lllllllll}
\hline & Median & Min & Max & \multicolumn{2}{l}{$\begin{array}{l}\text { Lower } \\
\text { quartile quartile }\end{array}$} & $\begin{array}{l}\text { Upper } \\
\text { range }\end{array}$ & Range & \multicolumn{2}{l}{$\begin{array}{l}\text { Interquartile } \\
\text { ranness }\end{array}$} \\
\hline Positive mental attitude & 18.00 & 13.00 & 23.00 & 15.00 & 20.50 & 10.00 & 5.50 & 0.03 \\
$\begin{array}{l}\text { Satisfaction with training } \\
\text { progress }\end{array}$ & 6.50 & 2.00 & 10.00 & 5.50 & 8.50 & 8.00 & 3.00 & -0.49 \\
\hline
\end{tabular}




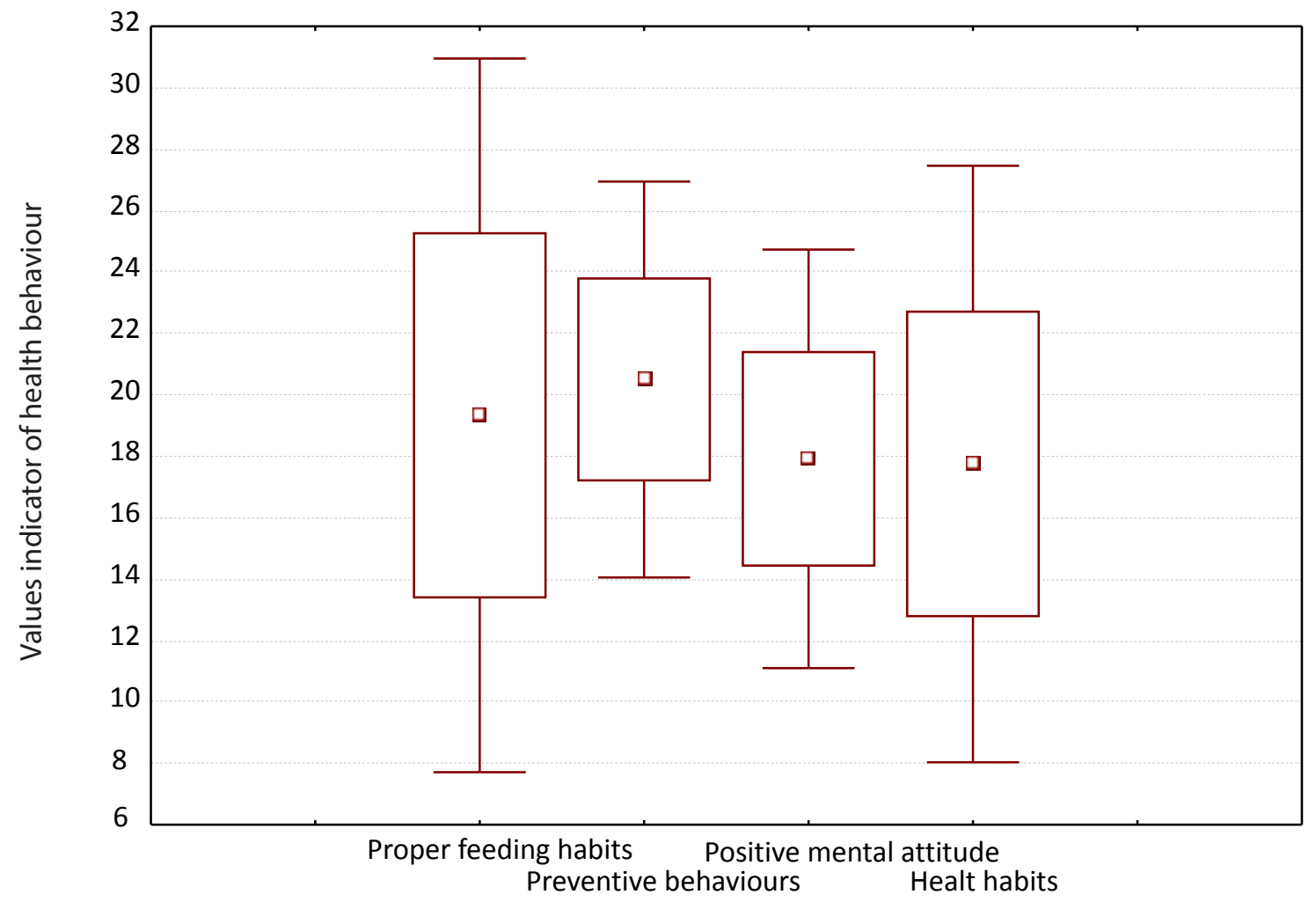

Figure1. The health-related behavior - descriptive analysis (Mean, Mean \pm SD, Mean \pm 1.96 SD)

Table 4. Healthy behaviours and feeling of personal competence - after K-Means clustering (cluster 1 and cluster 2 ). The table represents the result of cluster analysis with the use of K-Means Clustering: variance inside clusters.

\begin{tabular}{lll}
\hline After K-Means clustering. Variable: & Variance & \\
& Cluster $\mathbf{1}$ & Cluster 2 \\
\hline Age & 25.90 & 36.26 \\
Proper feeding habits & 11.20 & 13.86 \\
Preventive behaviours & 8.16 & 11.36 \\
Positive mental attitude & 4.26 & 4.16 \\
Health behaviours & 18.80 & 9.90 \\
Feeling of personal competence & 1.36 & 4.56 \\
\hline
\end{tabular}

Table 5. How is a sense of personal competence of senior team in cycle speedway shaped?

\begin{tabular}{lllllllll}
\hline $\mathbf{N = 1 2}$ & Median & Minimum & $\max$ & $\begin{array}{l}\text { Lower } \\
\text { quartile }\end{array}$ & $\begin{array}{l}\text { Upper } \\
\text { quartile }\end{array}$ & Range & $\begin{array}{l}\text { Interquartile } \\
\text { range }\end{array}$ & kewness \\
\hline $\begin{array}{l}\text { Age } \\
\begin{array}{l}\text { Feeling of personal } \\
\text { competence }\end{array}\end{array}$ & 26.50 & 20.00 & 37.00 & 22.50 & 31.50 & 17.00 & 9.00 & 0.30 \\
\hline
\end{tabular}

Another question was, do top competitors, representing the highest level in cycle speedway, constitute a homogeneous group in terms of health behaviour shown and a sense of personal competence? In the sample group, clusters were identified on the basis of $F$ values and levels of significance $(p<0.05)$ (Table 3 , Figure 3$)$.

\section{Discussion}

Considering the frequency of the occurrence of certain health behaviour indicated by the persons in the research, the general index of the revealed health behaviour types and the values of indexes of certain sub-scales, measuring particular types of health behaviour such as proper eating habits, preventive behaviour, positive mental approach, and health practices, were measured. 


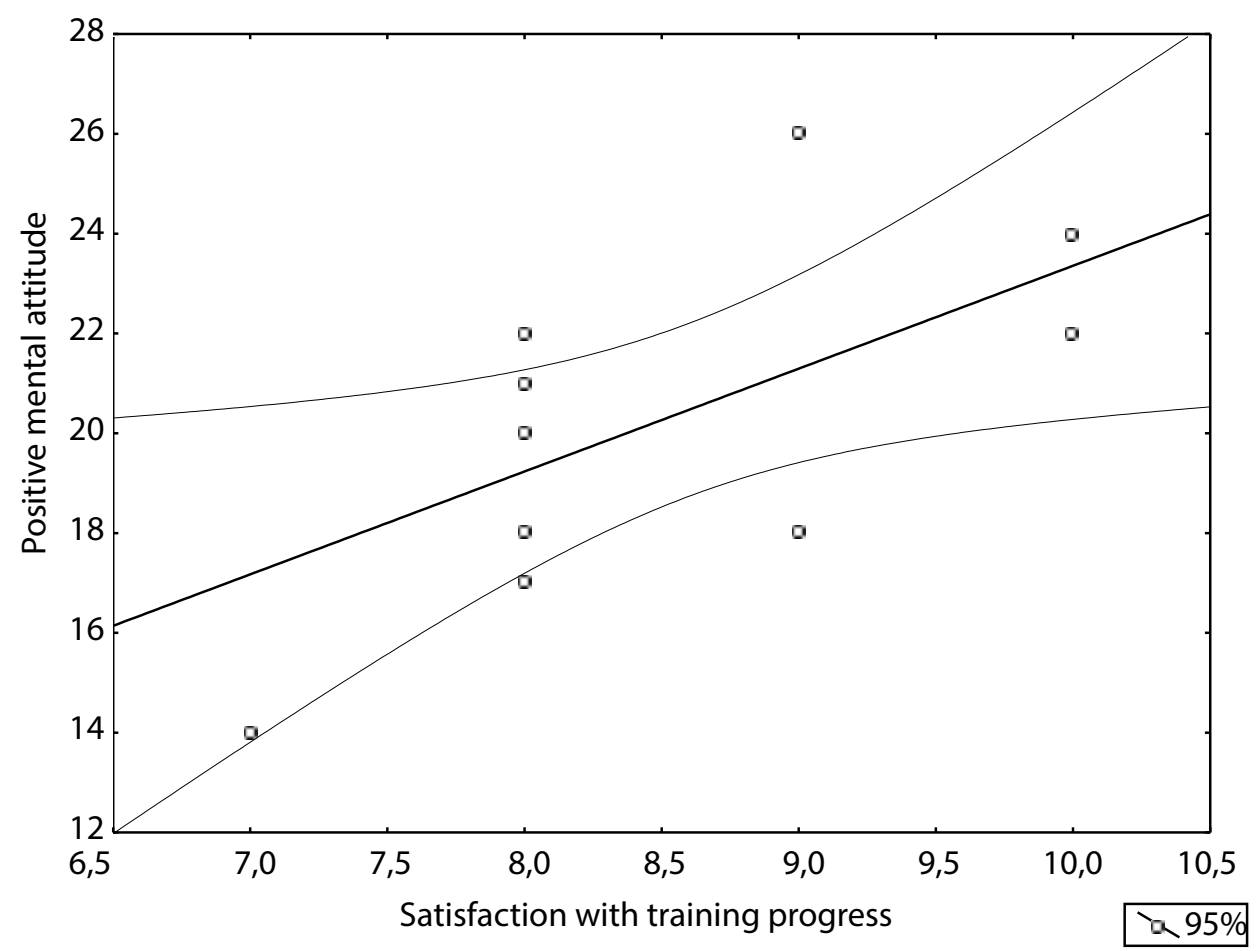

Figure 2. Relationship between positive mental attitude and the satisfaction with training progress $(r=0.62 ; p<0.05)$

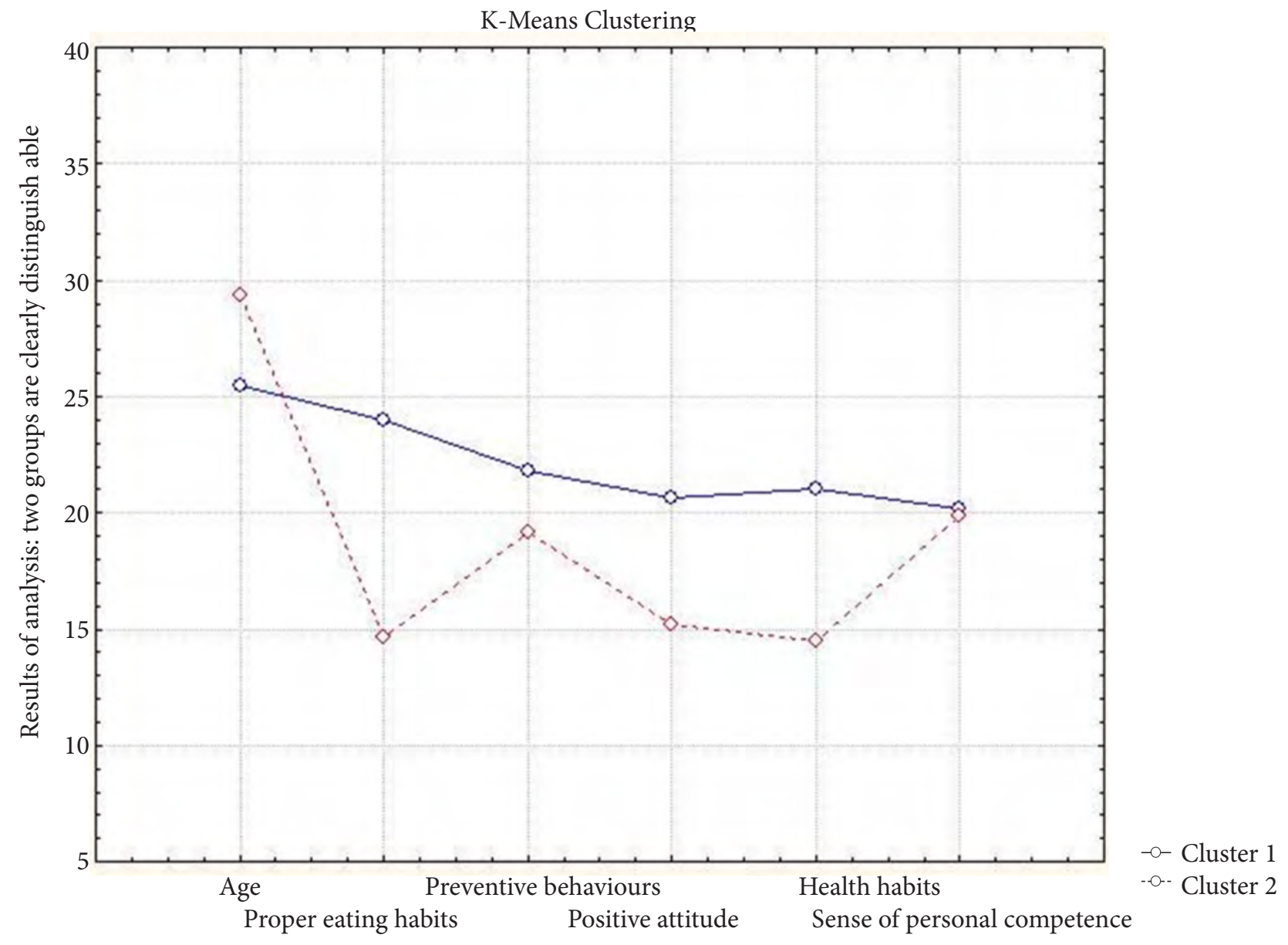

Figure 3. The diagram represents the result of cluster analysis with the use of k-means clustering senior team in cycle speedway sample group. Minimizing variance inside clusters-maximizing between clusters $(N=12)(p<0.05)$ 


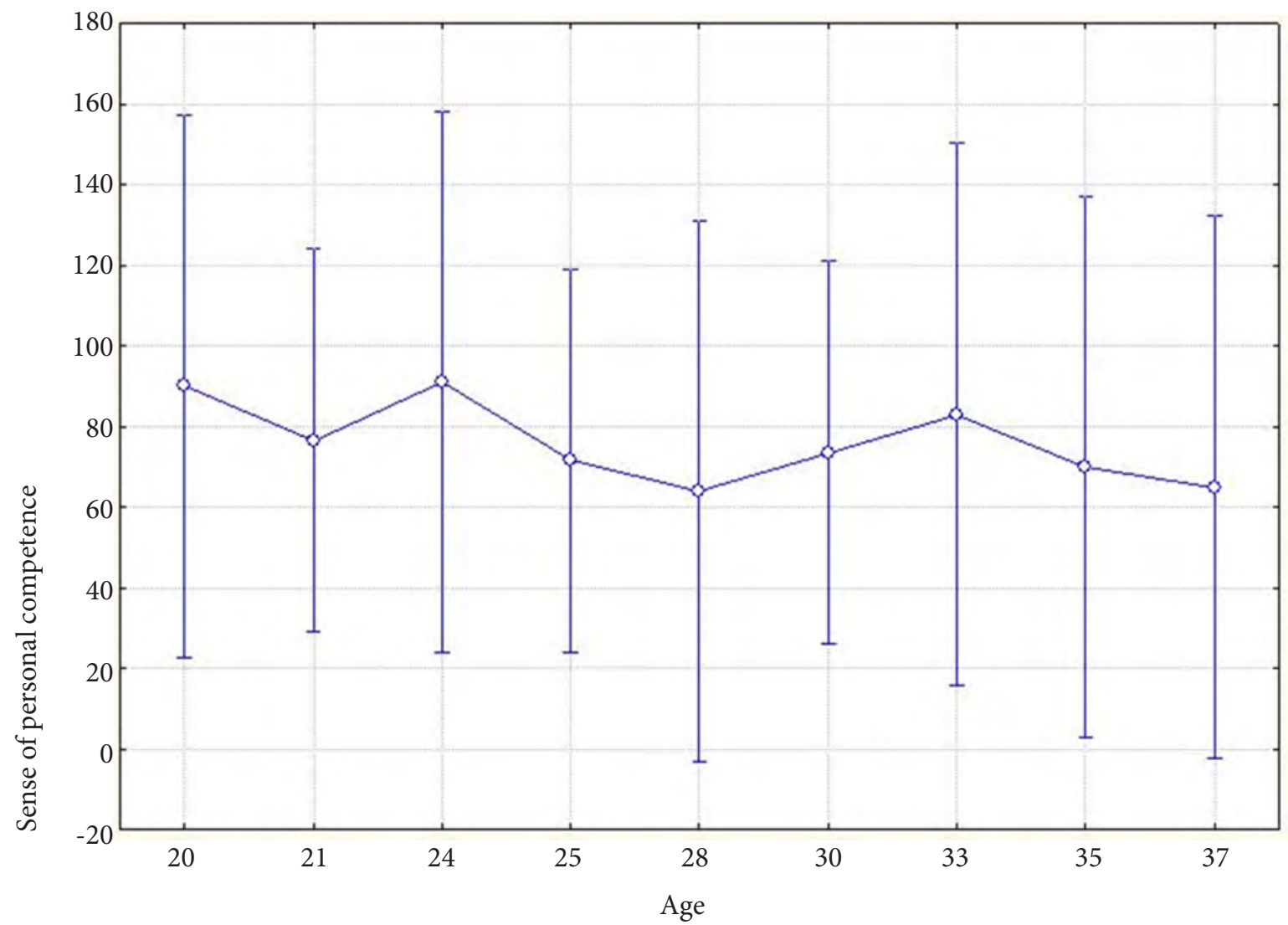

Figure 4. The diagram represents the result of analysis age and feeling of personal competence.

Based on the answers obtained in the Health Behaviour Inventory, it was found that concerning proper eating habits in the group the result was median 18.50, range 19; the value of the preventive behaviour index was 21.50, range 12 . The median value of positive mental approach was 18 (range 10), while the value of the health practices index was 17 (range 14). The precise data for these results are presented in Table 2 and Chart 1.

The value of the coefficient between positive mental approach and satisfaction experienced by the competitors caused by progress within a year was $r=0.62$; $\mathrm{p}<0.05$; $\mathrm{N}=12$ (Chart 2). In the group the value of the index of satisfaction caused by achieved progress in improving condition (during a year) was: median 6.50 (Table 3).

Another question asked was whether the examined competitors constitute a homogeneous group with respect to revealed health behaviour types and the feeling of personal competence (Table 4) and what the feeling of competence in a group of competitors with respect to stamina in undertaken activities is (Table 5, Chart 4).

The present research measured particular health behaviour based on the frequency of revealed behaviour types, including proper eating habits, preventive behaviour, applied health practices and positive mental approach. The values of the parameters are presented in Table 2. The mean value of the general health behaviour index was $75.50(\mathrm{SD}=14.0)$, which is a lower value in comparison with the results of other groups referred to in the literature [7]. Due to the lack of such data with respect to cycle speedway, we could not make a comparison within competitors of the same sport discipline.

In order to perform the taxonomic analysis of the persons taking part in the research, based on obtained health behaviour indexes, the above-mentioned cluster analysis that includes the methods used to identify homogeneous sub-groups among the members of a heterogenic population was applied. Based on the performed analysis (with the k-means method) it was found that for the health behaviour types in the group of cycle speedway competitors there were two smaller groups (clusters): cluster no. 1 and cluster no. $2(\mathrm{p}<0.05)$ (Table 4, Chart 3).

The obtained results indicate that higher mean values of proper eating habits, such as drawing attention to the proportions of eaten products that also have a specific composition, and the amounts of vegetables, fruit and protein, were identified in cluster no. 1 (Table 4), with a lower average age $(\mathrm{F}=20.85 ; \mathrm{p}<0.05)$. Compared with sub-group no. 2 , in sub-group no. 1 there is a higher mean value of the applied health practices index $(F=21.52 ; p<0.05)$. Table 4 presents descriptive statistics of particular health behaviour in a group, with the division into two identified sub-groups. No significant difference between the selected sub-groups with respect to the feeling of personal competence was found, as the difference between mean values did not reach statistical significance $(F=1.08 ; p=0.322)$.

The obtained results (presented in this paper) to a 
certain extent may correspond with the literature of the subject, indicating that health behaviour does not constitute a fully homogeneous notion construct and in the case of one person there might occur various behaviours associated with health care. Some are more desirable, due to the training aims, while some are less desirable.

Based on the calculations, we may assume that there is a correlation between positive mental approach and satisfaction caused by an increase of one's condition as a result of systematic training $(\mathrm{r}=0.62 ; \mathrm{p}<0.05 ; \mathrm{N}=12)$ (Chart 2). Based on the statistical descriptive analysis, it was concluded that in the group there are high values of mental positive approach indexes (median 18, range 10) (Table 3).

The obtained result corresponds with the reports of other authors indicating that positive emotions that accompany a positive mental approach and progress in professional sport often coexist [11, 12]. The research devoted to the development of championship level cycling in the UK stresses the role of the coherence of physical and mental preparation [13, 14]. It complies with the widespread belief, supported with the results of research, that psychological factors and a positive mental approach play a significant role in many, if not all, fields of sport activity [15-18]. For instance, the ability to maintain concentration, despite distracting thoughts, and the ability to concentrate on performed tasks of a different degree of complexity, is commonly considered to be a very important factor in obtaining sport results [19].

In the present research, analysing the data concerning the revealed feeling of competence, attention was drawn to the aspect that refers to the self-assessment of stamina in continuing activities.

The research indicates how large the number of tasks initiated and never finished or only partially finished, performed within the presumably properly prepared schedules, is [8]. In the light of research, based on the obtained mean value of the feeling of competence index, with respect to the possibilities of continuing an undertaken activity, we may assume that the index value is relatively high (Table 5). The obtained result corresponds with the reports of research on the relation between the feeling of competence and self-confidence in the case of competitors who constitute the elite of a particular discipline. The sense of self-efficacy expresses a subjective belief about one's impact on the surrounding reality; it has regulatory power [2, 5, 6, 20].

Based on the obtained results, no positive correlation between the feeling of competence and the age of cycle speedway competitors was found (Chart 4).

In the light of literature on health psychology, individuals are active processors of information and not passive reactors. The biopsychosocial model considers many diversified factors [20]. A man actively proceeds information and does not only constitute its passive recipient. This also refers to the feedback concerning the abilities of copying in different challenging situations. The authors draw attention to the fact that usually, in the majority of situations, high self-esteem is very helpful and it can, in some cases, become the source of less desirable behaviour such as lower involvement during training. However, generally, self-esteem and a high but adequate level of the feeling of competence plus the ability to accept feedback help in achieving [2].

Due to its specific nature, cycle speedway is a challenging discipline with respect to physical and mental aspects. It is connected with the risk of not using the bicycle brakes. The participants almost always come across situations in which the feeling of competence and trust with respect to one's possibilities may constitute the form of a buffer in situations of high pressure [21]. Psychological factors and a positive mental approach play an important role in many, if not all, fields of sport activities [15, 16, 18].

The obtained data correspond with the reports of other researchers indicating that a more positive mental approach coexists with higher satisfaction resulting from progress in training [2].

The research referred to in the literature proves the impact of internal monologues on the quality of performance. It is shown by the research meta-analysis covering 32 research analyses that proved the importance of internal monologues containing words such as: "I am able to do it, I am strong enough". Positive messages directed to oneself are considered to be helpful in obtaining a mental state that is in favour of good performance techniques [22].

In the light of the literature within sport psychology, a positive mental approach and trust in one's abilities have a considerable impact, as they increase the possibilities of acting, despite the existence of factors that distract attention, no matter what sub-discipline of cycling sport the competition is [21].

The examined group of cycle speedway competitors reveals a high value of the general feeling of competence index (Table 4, Feeling of personal competence). The value is slightly higher than the results obtained in other groups described in health psychology [23]. However, we must remember that the results presented here concern persons who, due to the level of skills, constitute an elite of cycle speedway in Poland. Further research should be directed towards a comparison with competitors from other countries but, similarly to the present research, should concern the leaders in cycle speedway, i.e. persons of very high skills in this discipline.

The results of our research indicate the need of further research on the factors that can predispose to stamina in an undertaken activity, aimed at reaching a high level of performance in cycle speedway and, to a wider extent, obtaining a championship level in a chosen sport discipline. The obtained results to some extent correspond with the reports of other researchers who indicate methodological difficulties in conducting research concerning stamina in continuing activities, indicating both the role of psychological factors of a relatively fixed character (personality factors) and the role of situational factors $[8,18]$.

In the literature of sports psychology, the model in 
which, besides comprehensive physical preparation, there are elements of psychological preparation is considered optimal [16, 17, 21]. Neglecting individual differences within psychological features among competitors potentially reduces the effects of preparation $[1,17,21$, 24]. In the literature of the subject within the last two decades there have been many studies that concern the perspective of a biopsychosocial model in the role of mental sphere and emotions, based on the corresponding research reports and everyday observations [15, 21, 24, 25].

The present research results indicate that a group of senior competitors representing Poland at the championship in 2015 in cycle speedway is internally divided with respect to the revealed health behaviour types (Table 4, Chart 3). Recognising the field in which functioning may be additionally optimised constitutes a vital aspect of preparing for a competition [12]. We hope that to some extent this study will support the development of knowledge within cycle speedway. On the way towards the full use of obtained skills, a competitor who practises the discipline performs considerable work, not only at the time directly devoted to training but also in between training sessions. The time is filled with activities in which a key role is played by the choices made by a competitor and concerning the aspects of everyday functioning that potentially co-create his chances during sport rivalry [17].

\section{Conclusions}

Based on the conducted research, it was found that the behaviour types associated with health in the group of cycle speedway competitors are heterogeneous and highly individualised. The group of senior competitors representing Poland at the championship in 2015 in cycle speedway is heterogeneous with respect to the revealed health behaviour types. In the light of the biopsychological model of functioning the result seems justified because this model takes into account the importance of individual differences between competitors within different aspects of human functioning on the way to the championship level.

A deeper statistical analysis revealed that these differences take place with respect to the proper eating habits and applied preventive behaviour. The mental approach indicates the interchange ability of satisfaction caused by progress in a year of training and other preparations. No correlation between cycle speedway competitors and their feeling of own competence was observed. The obtained results, including, first of all, the values or health behaviour indexes suggest that there are potential abilities to be used by competitors that, in the future, may mean further great and better results in the undertaken rivalry. The present research was of an explorative character. The obtained data allow us to make hypotheses that require further verification. The results prove the fairness of the assumptions concerning the lack of homogeneity of the group of leading competitors of cycle speedway representing Poland in the 2015 championship.
The available literature does not contain much research concerning the measurement of cycle speedway competitors at the championship level. We hope that this study provides data that can partially fill the gap. Furthermore, desirable health behaviors has a wide range of psychological and physiological beneficial health effect among diverse population in different conditions [26-28]. Additionally, it is necessary to mention that obtaining of maximum effectiveness is associated with effort, and other factors. Passiveness do not facilitate the persistence in realizing different long-terms sports and health goals [29].

The findings of the study, including primarily the values of health behaviour indicators, suggest that there are still potential opportunities to be used by competitors surveyed, which in the future may lead to continued excellent - as at present - and even better performance at competitive events. On the way to the optimal use of acquired skills (during championships, competitions, and preliminaries) a competitor training in cycle speedway performs enormous work, not just at the time directly devoted to training, but also in between training sessions. It is a time filled with activity, in which the choices made by a competitor regarding aspects of functioning which potentially contribute to his chances during the sports competition become crucial.

\section{Perspectives}

The results of the study indicate the usefulness of involving measurement of eating habits, mental attitude and preventive behaviours to understand the determinants of effectiveness in cycle speedway. This issue should be considered at the intersection of several disciplines (sports science, nutrition science and sports psychology). Clinical practice with scientific research strengthens and multiplies the effects. The results of our research have shown that not all nutritional options as support for other elements of the preparation process have been used by the riders. In the long term, cycle speedway riders' eating habits can be improved thanks to their cooperation with a nutrition specialist such as a dietitian and an expert on nutrition of sportspeople. Psychological assistance here could take the form of support in achieving regularity during the implementation of habits related to eating. Creating and consolidating habits on many levels would be conducive to the reduction of effort while aiming at making better choices about food. This is because automation is an important factor in achieving training goals.

\section{Acknowledgements}

The authors would like to express their sincere thanks to the coach and the Polish national cycle speedway team for making this study possible.

\section{Concflict of interests}

The authors declare that thare is no conflict of interests. 


\section{References}

1. Obree G. The Obree Way. A Training Manual for Cyclists. London: Bloomsbury Sport; 2013.

2. Tod D, Hardy J, Oliver E. Effects of Self-Talk: A Systematic Review. J Sport Exercise Psy, 2011; 33: 666-687.

3. Lipoński W. World Sports Encyclopedia. Poznań: Atena; 2003.

4. Abraham Ch, Conner M, Jones F, O'Connor D. Health Psychology. London: Hodder Education; 2008.

5. Barwood MJ, Corbett J, Wagstaff CR, McVeigh D, Thelwell RC. Improvement of $10-\mathrm{km}$ time-trial cycling with motivational self-talk compared with neutral self-talk. Int $J$ Sports Physiol Perform 2015; 10(2): 166-171.

6. Jones G, Hanton S, Connaughton D. What Is This Thing Called Mental Toughness? An Investigation of Elite Sport Performers. J Appl Sport Psychol 2002; 14: 205-218.

7. Juczyński Z. Health in the Hierarchy of Personal Values of Children and Youth. Family Pedagogy, 2014; 4(1): 67-79.

8. Luszczyńska A, Scholz U, Schwarzer R. The general selfefficacy scale: multicultural validation studies. The Journal of Psychology, 2005; 139: 439-457.

9. Upton G, Cook I. A Dictionary of Statistics. Oxford: Oxford University Press; 2008.

10.Miao Y, Wang R, Adler A. Limit theorems for order statistics from exponentials. Stat Probabil Lett, 2016; 110: 51-57.

11.Cohen R. Sport Psychology: The Basics: Optimising Human Performance. London: Bloomsbury Sport; 2016.

12.Krane V, Williams JM. Psychological characteristics of peak performance, In: Williams JM, Krane V. (Eds.), Applied Sport Psychology. Personal Growth to Peak Performance. New York: McGraw-Hill Education, 2015. P. 159-175.

13.Kirkland A, Hopker J, Jobson SA. Learning from the success of British cycling - perspectives on developing excellence in practice. The Sport and Exercise Scientist, 2013; 35: 22-23.

14.Sidwells C. Complete Bike Book. Choosing, Riding, and Maintaining Your Bike. London: Dorling Kindersley; 2003.

15.Chin NS, Khoo S, Low WY. Self-determination and goal orientation in track and field. J Hum Kinet, 2012; 33: 151161.

16.Lane AM, Beedie CJ, Devonport TJ, Stanley DM. Instrumental emotion regulation in sport: relationships between beliefs about emotion and emotion regulation strategies used by athletes. Scand J Med Sci Sports, 2011;
21(6): e445-e451. doi:10.1111/j.1600-0838.2011.01364.x

17.Le Bars H, Gernigon C, Ninot G. Personal and contextual determinants of elite young athletes' persistence or dropping out over time. Scand J Med Sci Sports, 2009; 19: 274-285. doi:10.1111/j.1600-0838.2008.00786.x

18.Iso-Ahola SE. Intrapersonal and interpersonal factors in athletic performance. Scand J Med Sci, 1995; 5: 191-199. doi:10.1111/j.1600-0838.1995.tb00035.x

19.Nideffer RM. Concentration and attention control training. In: Williams J. (Eds.), Applied Sport Psychology. Personal Growth to Peak Performance. Palo Alto: Mayfield; 1993. P. 243-262.

20.Dishman RK, Chambliss HO. Exercise psychology. In: Williams JM, Krane V. (Eds.), Applied Sport Psychology. Personal Growth to Peak Performance. New York: McGrawHill Education; 2015. P. 510-540.

21.Rabin M, Hicks R. The Pain-Free Cyclist. Conquer Injury and Find Your Cycling Nirvana. London: Bloomsbury; 2015.

22.Yeager S. Get Fast! A Complete Guide to Gaining Speed Wherever You Ride. New York: Rodale; 2013.

23.Emmerman J. Sport psychology and cycling: the mind-body relationship. In: Hopker J, Jobson S. (Eds.), Performance Cycling. The Science of Success. London: Bloomsbury; 2011. P. 138-146.

24.Rhoden CL, West J, Renfree A, Corbett M, St Clair Gibson A. Adaptive self-regulation in cycle time trials: goal pursuit, goal disengagement and the affective experience. $J$ Sci Cycling, 2015; 4: 49-57.

25.Kreausukon P, Gellert P, Lippke S, Schwarzer R. Planning and self-efficacy can increase fruit and vegetable consumption: a randomized controlled trial. J Behav Med, 2012; 35: 443451.

26.Druz VA, Iermakov SS, Nosko MO, Shesterova LY, Novitskaya NA. The problems of students' physical training individualization. Pedagogics, psychology, medical biological problems of physical training and sports, 2017; 21 (2): 51-59. doi:10.15561/18189172.2017.0201

27.Wąsik J, Wójcik A. Health in the context of martial arts practice. Physical Activity Review, 2017; 5: 91-94.

28.Spałek R, Ortenburger D, Szerla M, Bitner B. Musculoskeletal pain as a challenging problem for patients and occupational therapists. Physical Activity Review, 2017; 5: 196-201.

29.Wąsik J, Góra T. Impact of target selection on front kick kinematics in taekwondo - pilot study. Physical Activity Review, 2016; 4: 57-61.

\section{Information about the authors:}

Bakota Daniel (Corresponding author); http://orcid.org/0000-0002-5056-1928; d.bakota@ajd.czest.pl; Institute of Physical Education, Tourism and Physiotherapy, Jan Dlugosz University of Częstochowa; Waszyngtona 4/8 Street, 42-200 Częstochowa, Poland.

Ortenburger Dorota; http://orcid.org/0000-0003-4554-9024; dorotaortenburger@gmail.com; Institute of Physical Education, Tourism and Physiotherapy, Jan Dlugosz University of Częstochowa; Waszyngtona 4/8 Street, 42-200 Częstochowa, Poland.

Płomiński Arkadiusz; http://orcid.org/0000-0002-0779-4830; a.k.plominski@wp.pl; Institute of Physical Education, Tourism and Physiotherapy, Jan Dlugosz University of Częstochowa; Waszyngtona 4/8 Street, 42-200 Częstochowa, Poland.

Cite this article as: Bakota D, Ortenburger D, Płomiński A. Selected aspects of biopsychosocial functioning of the senior national team in cycle speedway representing Poland in 2015 at the World Championships in Poole. Pedagogics, psychology, medicalbiological problems of physical training and sports, 2018;22(2):68-76. doi:10.15561/18189172.2018.0202

The electronic version of this article is the complete one and can be found online at: http://www.sportpedagogy.org.ua/index.php/PPS/issue/archive

This is an Open Access article distributed under the terms of the Creative Commons Attribution License, which permits unrestricted use, distribution, and reproduction in any medium, provided the original work is properly cited (http://creativecommons.org/licenses/by/4.0/deed.en).

Received: 22.10.2017

Accepted: 08.11.2017; Published: 30.04.2018 